\title{
Is low energy intake a risk factor for ischaemic heart disease?
}

\author{
ALAN J SILMAN, „ JEAN W MARR† \\ From the ${ }^{\star D}$ epartment of Clinical Epidemiology, London Hospital Medical College and the $\nmid$ Department of Clinical \\ Epidemiology and General Practice, Royal Free Hospital School of Medicine, London
}

SUMMARY The relation between total energy intake and the development of ischaemic heart disease was investigated from a review of all available data including the results of 26 years of follow up from a longitudinal study of diet and ischaemic heart disease. A consistent inverse relation was found, whose strength and consistency are similar to those of other established risk factors.

It is concluded that there may be a minimum energy intake below which the risk of ischaemic heart disease is increased.

The association of ischaemic heart disease mortality and dietary factors, between populations, was first identified more than 25 years ago $^{1}$ and subsequently confirmed by others. ${ }^{2-4}$ Positive associations were found not only with the proportion of energy from both total and saturated fat but also with total energy intake. ${ }^{56}$ Indeed it was postulated that excessive energy intake from all sources rather than from any one particular kind of food was associated with ischaemic heart disease. ${ }^{7} \mathrm{~A}$ prospective study in the United Kingdom of groups of bankers and London busmen, however, suggested that a high energy intake may be protective against ischaemic heart disease. ${ }^{8}$ We have subsequently examined available data from other diet-heart studies together with previously unpublished data from the UK study to determine whether this relation is consistent and to consider the possible explanations for such an association.

\section{Review of the evidence}

\section{OBSERVATIONAL STUDIES BETWEEN \\ POPULATIONS}

The findings from observational ecological studies (Table 1) showed245 that populations with a high ischaemic heart disease mortality are the affluent countries that also have high fat and energy levels available for consumption. The Seven Country study

Requests for reprints to Dr A J Silman, Department of Clinical Epidemiology, The London Hospital Medical College, London E1 1BB.

Accepted for publication 22 January 1985 by Keys ${ }^{10}$ using a diet methodology appropriate for characterising groups, ${ }^{11}$ found no relation between ischaemic heart disease and energy intake, calculated as energy per kilogram body weight. They did, however, find that there was less disease in the communities with high physical activity, though the relation between physical activity and energy intake was not examined.

\section{COMPARATIVE STUDIES OF RELATED}

POPULATIONS WITH DIFFERING RISKS

In a study comparing dietary habits in Boston men of Irish origin with those of their brothers remaining in Ireland 1213 the Irish brothers had a mean daily energy intake of $500 \mathrm{cal}_{\mathrm{th}}(2.10 \mathrm{MJ})$ more than their Bostonian counterparts despite being about $10 \%$ smaller in weight and having half the mortality rate due to ischaemic heart disease. The Irish brothers were noted to take more exercise.

In an attempt to explain the lower standardised mortality rate of ischaemic heart disease in Iowa farmers compared with their town dwelling counterparts the ischaemic heart disease risk factors were compared in the two groups. ${ }^{14}$ This showed that the farmers smoked less, exercised more frequently, and had a mean energy intake of $430 \mathrm{kcal}_{\mathrm{th}}(1.81 \mathrm{MJ})$ greater than the towns people. Conversely, the percentage fat intake was similar and the ratio of polyunsaturated to saturated fatty acids was lower in the farmers.

TIME TRENDS WITHIN POPULATIONS

Kahn observed that despite a fall of $10 \%$ in total energy intake in the United States in the first six 
Table 1 Between population comparisons of ischaemic heart disease mortality and dietary fat and energy intake

\begin{tabular}{|c|c|c|c|c|c|}
\hline Study & No of coumtries & $\begin{array}{l}\text { Population } \\
\text { (age range in yr) }\end{array}$ & Disease definition & Energy $\left(r_{s}\right)^{\star}$ & $\%$ Fat $\left(r_{s}\right)^{\star}$ \\
\hline $\begin{array}{l}\text { Yerushalmy and } \\
\text { Hilleboe } \\
\text { Jolliffe and Archer } \\
\text { Masironis }^{5}\end{array}$ & $\begin{array}{l}22 \\
20\end{array}$ & $\begin{array}{l}\text { Male }(55-59) \\
\text { Male }(55-59) \\
\text { Male }(55-64)\end{array}$ & $\begin{array}{l}\text { ICD: B25-28 } \\
\text { ICD: B26 } \\
\text { AHD }\end{array}$ & $\begin{array}{l}+0.64 \\
+0.55\end{array}$ & $\begin{array}{l}+0.44 \\
+0.73\end{array}$ \\
\hline $\begin{array}{l}1940 \text { s and } 1950 \text { s } \\
1960 \text { s }\end{array}$ & $\begin{array}{l}25 \\
38\end{array}$ & & & $\begin{array}{l}+0.75 \\
+0.69\end{array}$ & $\begin{array}{l}+0.63 \\
+0.74\end{array}$ \\
\hline
\end{tabular}

^Food energy data derived from Food and Agricultural Organisation food balance sheets. $r_{\mathrm{s}}$, Spearman's rank correlation coefficient. $\mathrm{AHD}$, arteriosclerotic and degenerative heart disease; ICD, international classification of diseases.

decades of this century there has been an increase in ischaemic heart disease rates though little change in serum cholesterol concentrations. ${ }^{15}$ Figure 1 shows similar data for the United Kingdom from 1960 to 1978 (that is, the period of the Eighth Revision of the International Classification of Diseases). There was an increase in age adjusted ischaemic heart disease mortality rate between 1960 and 1972 followed by a levelling off in both men and women. ${ }^{16} 17$ During this period there was a steady decline in energy intake, which was particularly pronounced in 1970-74. ${ }^{18}$ Statistically, for the 19 years, there are strong inverse correlations between this population estimate of energy intake and mortality in both men $(r=-0.78)$ and women $(r=-0.69)$.

\section{RETROSPECTIVE STUDIES}

In the International Atherosclerosis Project there was a trend of increasing coronary artery atheroma with a decrease in energy intake, though this was not statistically significant. ${ }^{19}$ In a similar study of 226 men from the Honolulu Heart Study both energy and starch intake were significantly inversely related to the extent of coronary atheroma at necropsy. ${ }^{20} \mathrm{~A}$ detailed case-control study in North Dakota, however, found no association between ischaemic heart disease and mean energy intake. ${ }^{21} 22$

\section{PROSPECTIVE STUDIES}

There have been several prospective studies involving dietary assessment. A part of the Western Collaborative Group study used a seven day diary method of dietary assessment. ${ }^{23} \mathrm{~A}$ two and a half year follow up showed that 25 men who developed electrocardiographic changes of ischaemic heart disease had a lower initial energy intake compared with 80 disease free men (2100 vs $2280 \mathrm{kcal}_{\text {th }}(8.82$ vs $9.58 \mathrm{MJ})$ ).

Not all prospective studies of diet and ischaemic heart disease have reported on total energy intake, though such data must have been collected. Thus there are no dietary data pertinent to this question either from the Albany ${ }^{24}$ or the Minnesota ${ }^{25}$ studies. We have found seven prospective population studies from which at least four years of follow up data are available. We grouped the studies into areas of high and low incidence of ischaemic heart disease because of the very different levels of energy intake found. The high incidence areas included Framingham, ${ }^{26} 27$ Zutphen, ${ }^{28}$ Western Electric (Chicago), ${ }^{29} 30$ and UK bankers and busmen ${ }^{831}$ and the low incidence areas Hawaii, ${ }^{32}$ and the studies of both urban and rural populations in Puerto Rico. ${ }^{33}$ The studies varied in their study population, the method of dietary inquiry, the outcome measures published, and the duration of follow up; Table 2 shows these differences.

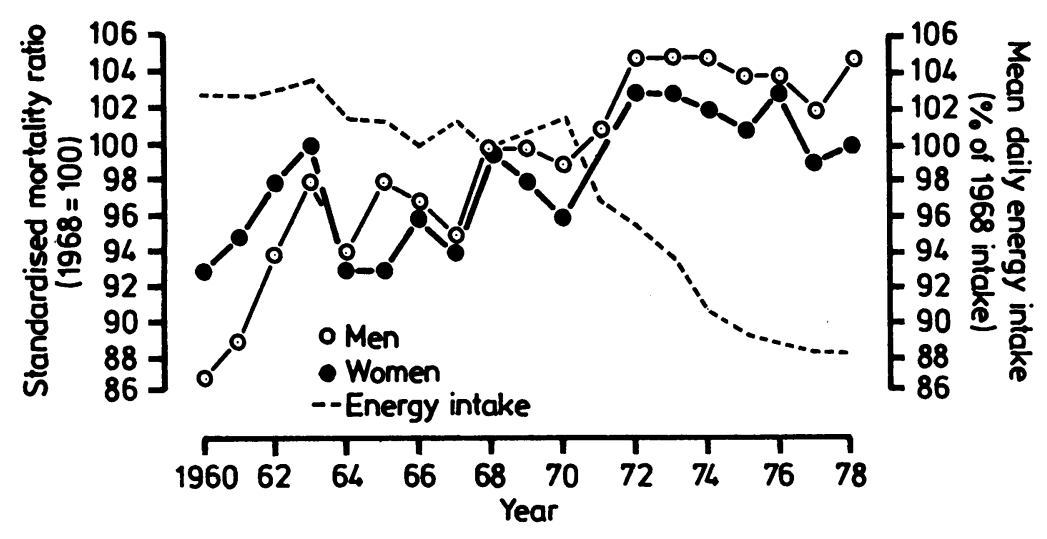

Fig. 1 Trends of heart disease mortality (ICD 410-414 Eighth Revision) and energy intake 1960-78. 
Table 2 Methodological details in prospective studies of diet and ischaemic heart disease

\begin{tabular}{|c|c|c|c|c|c|}
\hline Study & $\begin{array}{l}\text { Population } \\
\text { (age range in yr) }\end{array}$ & $\begin{array}{l}\text { No of } \\
\text { subjects }\end{array}$ & Dietary survey method & Adverse outcome & $\begin{array}{l}\text { Duration of } \\
\text { follow up } \\
(y r)\end{array}$ \\
\hline Framingham & Male (45-64) & 831 & 24 hour recall & $\begin{array}{l}\text { Death (ischaemic heart disease, acute myocardial } \\
\text { infarction) }\end{array}$ & 4 \\
\hline Zutphen & Male (40-59) & 770 & $\begin{array}{l}\text { Cross check } \\
\text { dietary history }\end{array}$ & Death (ischaemic heart disease) & 10 \\
\hline Western Electric & Male $(40-55)$ & 1885 & Dietary interview & $\begin{array}{l}\text { Death (ischaemic heart disease, acute myocardial } \\
\text { infarction, angina) }\end{array}$ & 4.4 \\
\hline $\begin{array}{l}\text { UK bankers and } \\
\text { busmen }\end{array}$ & Male (30-67) & 337 & $\begin{array}{l}\text { Seven day weighed } \\
\text { survey }\end{array}$ & $\begin{array}{l}\text { Death (ischaemic heart disease, acute myocardial } \\
\text { infarction, angina) }\end{array}$ & $10-20$ \\
\hline Hawaii & Male, Japanese & 7590 & 24 hour recall & $\begin{array}{l}\text { Death, (ischaemic heart disease, acute myocardial } \\
\text { infarction) }\end{array}$ & 6 \\
\hline $\begin{array}{l}\text { Puerto Rico } \\
\text { (Urban) }\end{array}$ & Male $(45-64)$ & 5714 & 24 hour recall & $\begin{array}{l}\text { Death (ischaemic heart disease, acute myocardial } \\
\text { infarction) }\end{array}$ & 6 \\
\hline $\begin{array}{l}\text { Puerto Rico } \\
\text { (Rural) }\end{array}$ & Male (45-64) & 2381 & 24 hour recall & $\begin{array}{l}\text { Death (ischaemic heart disease, acute myocardial } \\
\text { infarction) }\end{array}$ & 6 \\
\hline
\end{tabular}

Table 3 Mean energy intake and disease status from seven longitudinal studies

\begin{tabular}{|c|c|c|c|c|c|c|c|c|}
\hline \multirow[t]{2}{*}{ Study } & \multicolumn{4}{|c|}{ Patients with heart disease } & \multicolumn{4}{|c|}{ Disease free subjects } \\
\hline & No & $\begin{array}{l}\text { Mean energy } \\
\text { intake } \\
\left.\text { (cal } l_{t h}\right)\end{array}$ & $S D$ & $S E E$ & No & $\begin{array}{l}\text { Mean energy } \\
\text { intake } \\
\left.\text { (cal } l_{\text {th }}\right)\end{array}$ & $S D$ & $S E E$ \\
\hline $\begin{array}{l}\text { Framingham } \\
\text { Zutphen } \\
\text { Western Electric } \\
\text { UK bankers and busmen }\end{array}$ & $\begin{array}{l}51 \\
27 \\
88 \\
50\end{array}$ & $\begin{array}{l}2369 \\
2857 \\
3082 \\
2656\end{array}$ & $\begin{array}{l}700^{\star} \\
582 \\
974^{\star} \\
400\end{array}$ & $\begin{array}{c}\text { High incidence areas } \\
98.0 \\
112.0 \\
103.8 \\
56.6 \\
\text { Low incidence areas }\end{array}$ & $\begin{array}{r}780 \\
743 \\
1797 \\
287\end{array}$ & $\begin{array}{l}2622 \\
3080 \\
3174 \\
2869\end{array}$ & $\begin{array}{l}700^{\star} \\
662 \\
974^{\star} \\
505\end{array}$ & $\begin{array}{l}25 \cdot 1 \\
24 \cdot 3 \\
23 \cdot 0 \\
29 \cdot 8\end{array}$ \\
\hline $\begin{array}{l}\text { Honolulu } \\
\text { Puerto Rico (urban) } \\
\text { Puerto Rico (rural) }\end{array}$ & $\begin{array}{r}179 \\
129 \\
34\end{array}$ & $\begin{array}{l}2125 \\
2242 \\
2113\end{array}$ & $\begin{array}{l}666 \\
856^{\star} \\
837^{\star}\end{array}$ & $\begin{array}{r}49.8 \\
75.4 \\
143.5\end{array}$ & $\begin{array}{l}7411 \\
5585 \\
2347\end{array}$ & $\begin{array}{l}2290 \\
2413 \\
2353\end{array}$ & $\begin{array}{l}738 \\
856^{\star} \\
837^{\star}\end{array}$ & $\begin{array}{r}8.6 \\
11.5 \\
17.3\end{array}$ \\
\hline
\end{tabular}

* Pooled standard deviation (SD) from patients and disease free subjects.

SEE, standard error of the estimate

Conversion: traditional to SI units-energy intake: $1 \mathrm{cal}_{\mathrm{th}} \approx 4.2 \mathrm{~J}$.

Table 3 shows the mean energy intakes of those who did and did not develop ischaemic heart disease. It was necessary, in the absence of complete data, to use pooled standard deviations from both ischaemic heart disease patients and disease free subjects for the Framingham, Western Electric, and both the Puerto Rico population studies. This assumed that the variances were similar in the ischaemic heart disease patients as in disease free subjects. Though there was no a priori reason that they were different, a higher variance for the patients would have reduced the chances of any observed difference being statistically significant. The studies where separate data were available showed, however, that the variance tended to be lower for the patients (Table 3).

The most striking finding was that in each study the men developing ischaemic heart disease had, initially, a lower energy intake than the disease free men (Fig. 2), the difference varying between 100 and $250 \mathrm{kcal}_{\text {th }}$ $(0.42$ and $1.05 \mathrm{MJ})$ per day. These differences were significant for the Framingham, UK bankers and busmen, Hawaii, and the Puerto Rico (urban) studies. The data were pooled for both the combined high incidence areas and the combined low incidence areas.
The design of the studies in the low incidence areas was identical, but this was not true for the high incidence areas (Table 2). Though the pooling would increase the chances of a statistically significant result by increasing the sample size, it nevertheless is of use in providing the best estimate of the true difference. Calculated $95 \%$ confidence intervals for the deficit in energy intake in ischaemic heart disease cases are for high incidence areas $141.4-278.6 \mathrm{kcal}_{\text {th }}(0.59$ and 1.17 $\mathrm{MJ})$ per day and for low incidence areas 96.6-253.4 $\mathrm{kcal}_{\mathrm{h}}(0.41$ and $1.06 \mathrm{MJ})$ per day. The difference in means represents a shift to the left in the distribution of energy intake in the cases of ischaemic heart disease of $7.0 \%$ in the high incidence and $7.5 \%$ in the low incidence areas. It should be noted, however, that the difference in intake between high and low risk areas is greater than that between patients and disease free subjects within each of these two areas (Table 3).

\section{Discussion}

The evidence reviewed above is surprisingly consistent in suggesting an inverse association between energy intake and ischaemic heart disease risk within 


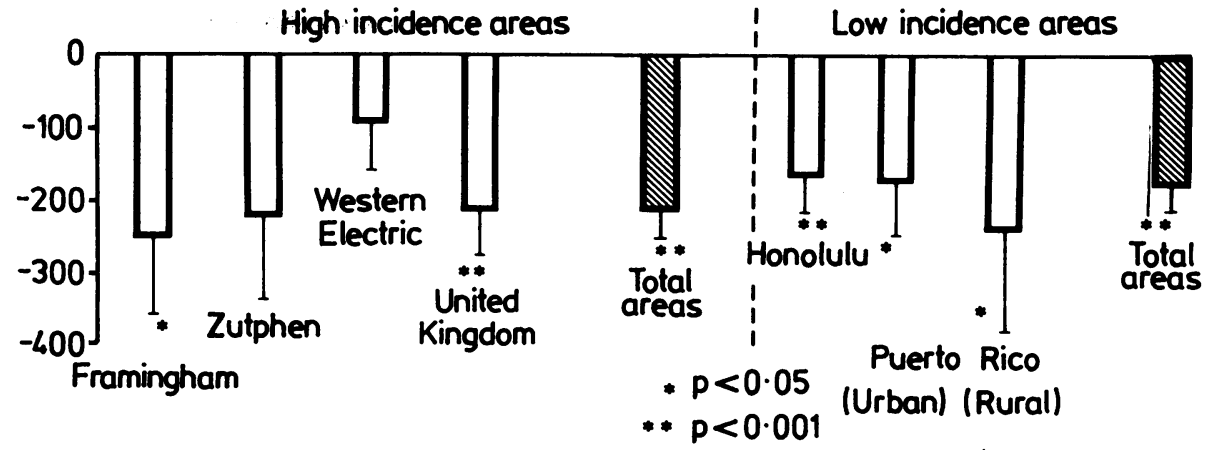

Fig. 2 Difference and standard error of difference of total mean daily energy intake between patients with coromary artery disease and disease free subjects from seven logitudinal studies. population groups and conflicts with the evidence of the comparisons between countries ${ }^{4} 5$ that countries with high levels of energy available for consumption have higher levels of ischaemic heart disease. The likely explanation for this paradox is that differences in energy intake between countries reflect relative affluence, and it is other variables associated with affluence that are the cause of the increased risk. The apparant protective effect of a high energy intake as suggested by the other studies described could possibly be explained by methodological problems and the possibility of confounding variables.

\section{METHODOLOGICAL PROBLEMS}

The association over time (Fig. 1) might be spurious. The National Food Survey data covered only food consumed at home, and during this period there had been an increase of $7 \%$ in meals taken away from home. ${ }^{34}$ Thus apart from all the other hazards in interpreting such associations the data may not truly represent energy intake. Similarly, the retrospective studies cited ${ }^{19-22}$ have to be interpreted with caution. Dietary inquiry in a retrospective or case-control study is open to error. Firstly, current diet may have altered as a result of disease presence and, secondly, a retrospective diet history is itself prone to error owing to poor recall.

The prospective studies cited used a single estimate of energy intake that might not reflect true intake over the duration of the study. Morris et al found a correlation of $\mathbf{0 . 7 3}$ within subjects for total energy intake calculated from two seven days weighed surveys performed one to 12 months apart. ${ }^{35}$ Although the men in the Zutphen study showed pronounced changes between 1960 and 1965 and 1965 and $1976^{36}$ there is no indication that the ranked order also changed. Thus, though diet does change, the originally observed differences are probably sustained. Furthermore, it is unlikely that any change over time is selectively different in direction between the ischaemic heart disease and disease free groups before the clinical onset of the disease. Secondly, the methods of dietary inquiry varied, and different end points and duration of study were used (Table 2). Estimates of energy intake from the methods used in all these studies probably underestimate true consumption. ${ }^{37}$ The results were, however, similar and this consistency, despite the differences in method, is positive evidence in favour of the results being real.

Thirdly, it is possible that in the short term follow up those already with incipient ischaemic heart disease at the start of the study may, as a consequence, have had a lower energy intake. The short (two and a half to six years) duration of some of the studies 232627293233 makes segregation between cause and effect difficult. The Zutphen men were, however, followed for 10 years, ${ }^{28}$ and 10-20 years data are available from the UK bankers and busmen study 8 with, at the time of writing, a further six years of follow up analysed (Marr and Morris, unpublished data). These data for the UK men, despite the small numbers in each follow up period, show that there was no evidence that the trend was reversing (Kendall's tau 0.155 , NS).

Fourthly, it is possible that obese persons may recall lower intakes. This possibility was examined in the Hawaii men, ${ }^{32}$ and the authors concluded, "age adjusted mean values of total calories were consistently lower in IHD cases than in non cases in all classes of relative weight."

Finally, it is unlikely that these results are chance findings. The standard deviations are large, but the pooling of the studies together showed that the likelihood of a type I error was less than $1 \%$.

\section{POSSIBLE CONFOUNDING VARIABLES}

It is possible that the relation to energy intake is explained by the confounding effect of other known ischaemic heart disease risk factors. The two most likely confounders are that both physical inactivity and cigarette smoking are associated with low energy intake, though the data are more substantive for the former. It was impossible, however, in the absence of direct access to all the raw data to do the necessary 
multiple logistic analyses to determine whether energy intake had an independent effect in the studies cited.

\section{ENERGY EXPENDITURE}

This is the likeliest confounding variable since in a steady state a high energy intake reflects increased muscular activity, ${ }^{8}$ and the latter is possibly protective against ischaemic heart disease. ${ }^{38} 39$ It has been found that a high energy expenditure is associated with an increased intake both in athletes ${ }^{4041}$ and office workers. 4243

In the prospective studies cited the patients with ischaemic heart disease in Hawaii ${ }^{31}$ had lower levels of physical activity $(p<0.05)$ compared with the disease free men, though the difference became statistically insignificant in multivariate analysis. The age adjusted mean energy intake was significantly lower in patients with ischaemic heart disease than in disease free subjects, even after controlling for physical activity.

The effect of increase in energy expenditure is, however, complex. Exercise does not, however, consistently increase the appetite. ${ }^{44} \mathrm{An}$ increase in daily exercise sufficient to produce weight loss over an eight week period did not increase energy intake, ${ }^{45}$ and 45 minutes of light jogging three days a week also had no effect. ${ }^{46}$ Indeed, in animals exercise may decrease the appetite. ${ }^{4748}$

\section{Cigarette smoking}

There are no data on whether cigarette smoking is associated with a reduction in energy intake compared with non-smokers. Anecdotally, patients who give up smoking report an increase in energy intake with increase in body weight, but whether this is a phenomenon of all non-smokers (never and exsmokers) is unknown. Analysis of the UK men, with smokers and non-smokers separately divided into equal high and low energy intake groups, showed that in both smoking groups the high intake group had approximately half the risk for ischaemic heart disease of the low intake group. ${ }^{8}$

\section{BIOLOGICAL PLAUSIBILITY}

In the absence of a plausible biological explanation a causal relation between low energy intake and ischaemic heart disease cannot easily be inferred from these data. ${ }^{49}$ The only likely explanation is that high energy intake is associated with an increase in plasma high density lipoprotein cholesterol concentration, though this might be explained by the confounding effect of energy expenditure.

The results of an intervention study comparing the effect of an exercise programme with sedentary controls on energy intake, body weight, and blood lipid concentrations $^{50}$ showed an identical positive relation between mileage run with both increase in energy intake $(r=0.48, p=0.006)$ and increase in plasma high density lipoprotein cholesterol concentration $(r=0.48$, $p=0.006$ ). The increase in energy intake included an increase in total fat consumption. It has, however, been shown that mild exercise in middle aged sedentary men has a favourable effect only on high density lipoprotein cholesterol concentration when energy intake is maintained; a reduction in intake leads to a reduction in high density lipoprotein concentration. ${ }^{51}$ Thus perhaps increased exercise and increased energy intake act synergistically in reducing ischaemic heart disease risk rather than as confounding variables. An alternative hypothesis is to consider the effect that ischaemic heart disease risk is related to trace element deficiency in the diet, 5253 and thus those with a high energy intake, assuming that they eat more of everything, might be less likely to show such deficiencies. Such hypotheses are virtually impossible to test without detailed and repeated chemical analyses of food and drink consumed, food tables being inadequate for the purpose. Such a methodology is likely to be unacceptable in free living populations participating in a prospective study.

\section{BIOLOGICAL IMPORTANCE}

It is of interest to note, however, that if the inverse association is causal its strength is high enough to be of biological importance. The observed difference in mean energy intakes represents a shift in the distribution, and a comparable shift, in proportionate terms, applied to other known risk factors would be likely to have a major effect on ischaemic heart disease rates. ${ }^{54}$ As an example, the data from the UK bankers and busmen study ${ }^{8}$ are given in Table 4 , which shows that the magnitude of the difference observed in energy intake is comparable to the difference observed with

Table 4 Relative difference in risk factors between men with ischaemic heart disease (group 1) and disease free men (group 2) ${ }^{8}$

\begin{tabular}{|c|c|c|c|}
\hline Variable & Group 1 & Group 2 & Difference in group 1 as $\%$ of group 2 \\
\hline $\begin{array}{l}\text { Mean serum cholesterol concentration }(\mathrm{mmol} / \mathrm{l}) \\
\text { Mean systolic blood pressure }(\mathrm{mm} \mathrm{Hg}) \\
\text { Mean No of cigarettes per day } \\
\text { Mean energy intake }\left(\mathrm{kcal}_{\mathrm{th}}\right)\end{array}$ & $\begin{array}{l}6 \cdot 46 \\
144 \\
15 \cdot 1 \\
2656\end{array}$ & $\begin{array}{c}6.05 \\
138 \\
9.4 \\
2869\end{array}$ & $\begin{array}{l}+6 \cdot 8 \\
+4 \cdot 3 \\
+60.6 \\
-7 \cdot 4\end{array}$ \\
\hline
\end{tabular}

Conversion: traditional to SI units-energy intake: $1 \mathrm{kcal}_{\mathrm{th}} \approx 0.0042 \mathrm{MJ}$. 
serum cholesterol concentration or systolic blood pressure.

\section{Conclusion}

There appears to be paradoxically an inverse association between energy intake and ischaemic heart disease risk within countries whose strength and consistency are similar to those of other established risk factors. The confounding effect of exercise or indeed other risk factors cannot be entirely discounted, though there is evidence that high energy intake and expenditure are synergistic.

There is no evidence that excessive energy intake in the absence of matched output is anything but harmful to health, ${ }^{55}$ but there is support, we believe, for the hypothesis that there is a minimum energy intake-probably higher than that needed to maintain body weight in the sedentary middle aged manbelow which the risk of ischaemic heart disease is increased.

\section{References}

1 Keys A. Atherosclerosis: a problem in newer public health. Fournal of the Mount Sinai Hospital 1953; 20: 118-39.

2 Yerushalmy J, Hilleboe HE. Fat in the diet and mortality from heart disease. NY State f Med 1957; 57: 2343-54.

3 Yudkin J. Diet and coronary thrombosis. Hypothesis and fact. Lancet 1957; ii: $155-62$.

4 Jolliffe N, Archer M. Statistical associations between international coronary heart disease death rates and certain environmental factors. $f$ Chronic Dis 1959; 9: 63652.

5 Masironi R. Dietary factors and coronary heart disease. Bull WHO 1970; 42: 103-14.

6 St Leger AS, Cochrane AL, Moore F. Factors associated with cardiac mortality in developed countries with particular reference to the consumption of wine. Lancet 1979; i: 1017-20.

7 Albrink MJ. Diet and cardiovascular disease. 7 Am Diet Assoc 1965; 46: 26-9.

8 Moriss JN, Marr JW, Clayton DG. Diet and heart: a postscript. Br Med f 1977; 2: 1307-14.

9 Keys A, ed. Coronary hear disease in seven countries. (American Heart Association Monograph Number 29.) New York: American Heart Association, 1970.

10 Keys A, ed. Seven countries. A multivariate analysis of death and coronary heart disease. Boston: Harvard University Press, 1980.

11 Marr JW. Individual dietary surveys: purposes and methods. World Rev Nutr Diet 1971; 13: 105-64.

12 Trulson MF, Clancy RE, Jessop WJE, Childers RW, Stare FJ. Comparisons of siblings in Boston and Ireland. f Am Diet Assoc 1964; 45: 225-9.

13 Brown J, Bourke GJ, Gearty GF, et al. Nutritional and epidemiologic factors related to heart disease. World Rev Nutr Diet 1970; 12: 1-42.

14 Pomrehn PR, Wallace RB, Burmeister LF: Ischemic heart disease mortality in Iowa farmers. $\mathcal{F A M A} 1982$; 248: $1073-6$.

$15 \mathrm{Kahn}$ HA. Change in serum cholesterol associated with changes in the United States civilian diet, 1909-1965. Am f Clin Nutr 1970; 23: 879-82.

16 Office of Population Censuses and Surveys. Registrar General. Statistical review of England and Wales for the year 1970. Part I Tables Medical. London: HMSO, 1972.

17 Office of Population Censuses and Surveys. Mortality statistics 1978. Series DHI No 6. London: HMSO, 1980.

18 Ministry of Agriculture Fisheries and Food. Annual reports of the National Food Survey Committee, 1960-1978. London: HMSO, 1962-1980.

19 Moore MC, Guzman MA, Schilling PE, Strong JP. Dietary-atherosclerosis study on deceased persons. F $\mathrm{Am}$ Diet Assoc 1976; 68: 216-23.

20 Rhoads CG, Blackwelder WC, Stermmermann GM, Hayashi T, Kagan A. Coronary risk factors and autopsy findings in Japanese-American men. Lab Invest 1978; 38: 304-11.

21 Zukel WJ, Lewis RH, Enterline PE, et al. A short term community study of the epidemiology of coronary heart disease. A preliminary report of the North Dakota Study. Am f Public Health 1959; 49: 1630-9.

22 Meredith AP, Enterline PE, Peterson B, Pekover JG. Implications in studying coronary heart disease. An epidemiologic diet study in North Dakota. I Am Diet Assoc 1960; 37: 339-43.

23 Rosenman RH, Friedman M, Straus R, Wurm M, Jenkins $\mathrm{CD}$, Messinger $\mathrm{HB}$. Coronary heart disease in the Western Collaborative Group Study. FAMA 1966; 195: 86-92.

24 Browe JH, Morlley DM, Logrillo VM, Doyle JT. Diet and heart disease in the cardiovascular health center. $\mathcal{J}$ Am Diet Assoc 1967; 50: 376-84.

25 Keys A, Taylor HL, Blackburn H, Brozek J, Anderson JT, Simonson E. Coronary heart disease amongst Minnesota business and professional men followed fifteen years. Circulation 1963; 28: 381-95.

26 Kannel WB, Gordon T, eds. The Framingham diet study: diet and the regulation of serum cholesterol. The Framingham Study. Section 24. Washington: US Government Printing Office, 1970.

27 Gordon T, Kagan A, Garcia-Palmieri M, et al. Diet and its relation to coronary heart disease and death in three populations. Circulation 1981; 63: 500-15.

28 Kromhout D, Bosschieter EB, Coulander CDL. Dietary fibre and 10-year mortality from coronary heart disease, cancer, and all causes. The Zutphen study. Lancet 1982; ii: $518-22$.

29 Paul O, Lepper MT, Phelan WH, et al. A longitudinal study of coronary heart disease. Circulation 1963; 28: 20-31.

30 Shekelle RB, Shryock-AM, Paul O, et al. Diet, serum cholesterol, and death from coronary heart disease. $N$ Engl f Med 1981; 304: 65-70.

31 Marr JW, Morris JN. Dietary intake and the risk of coronary heart disease in Japanese men living in Hawaii [Letter]. Am f Clin Nutr 1981; 34: 1156-7. 
32 Yano K, Rhoads GG, Kagan A, Tillotson J. Dietary intake and the risk of coronary heart disease in Japanese men living in Hawaii. Am $\mathcal{f}$ Clin Nutr 1978; 31: 1270-9.

33 Garcia-Palmieri MR, Sorlie P, Tillotson J, Costas R, Cordero E, Rodriguez M. Relationship of dietary intake to subsequent coronary heart disease incidence. The Puerto Rico Heart Health Program. Am $\mathcal{f}$ Clin Nutr 1980; 33: 1818-27.

34 King SHM: British Nutrition Foundation: eating behaviour and attiudes to food, nutrition and health. London: J Walter-Thompson, 1981.

35 Morris JN, Marr JW, Heady JA, Mills GL, Pilkington TRE. Diet and plasma cholesterol in 99 bank men. $\mathrm{Br}$ Med f 1963; 1: 571-6.

36 Kromhout $\mathrm{D}$. Changes in energy and macronutrients in 871 middle-aged men during 10 years of follow up (the Zutphen study). Am $\mathcal{F}$ Clin Nutr 1983; 37: 287-94.

37 James WPT. Energy requirements and obesity. Lancet 1983; ii: 386-9.

38 Paffenburger RS Jr, Wing AL, Hyde RT. Physical activity as an index of heart attack risk in college alumni. Am f Epidemiol 1978; 108: 161-75.

39 Morris JN, Everitt MG, Pollard R, Chave SPW. Vigorous exercise in leisure time. Protection against coronary heart disease. Lancet 1980; ii: 1207-10.

40 Blair SN, Ellsworth NM, Haskell WL, Stean MP, Farquhar JW, Wood PD. Comparison of nutrient intake in middle-aged men and women runners and controls. Med Sci Sports Exerc 1981; 13: 310-5.

41 Vodak PA, Wood PD, Haskell WL, Williams PT. HDL - cholesterol and other plasma lipid and lipoprotein concentrations in middle aged male and female tennis players. Metabolism 1980; 29: 745-52.

42 Yasin S, Alderson MR, Marr JW, Pattison DC, Morris JN. Assessment of habitual physical activity apart from occupation. Br F Prev Soc Med 1967; 21: 163-9.

43 Marr JW, Gregory J, Meade TW, Alderson MR, Morris
JN. Diet, leisure activity and skinfold measurements of sedentary men. Proc Nutr Soc 1970; 29: 17A-8A.

44 Oscai LB. The role of exercise in weight control. Exerc Sports Sci Rev 1974; 1: 103-23.

45 Dempsey JA. Anthropemetrical observations on obese and non-obese young men undergoing a programme of vigorous physical exercise. Research Quarterly of the American Association for Health, Physical Education and Recreation 1964; 35: 275-87.

46 Holloszy JO, Skinner JS, Toro G, Cureton TK. Effects of a six month program of endurance exercise on the serum lipids of middle-aged men. Am $\mathcal{F}$ Cardiol 1964; 14: 753-60.

47 Stevenson JAF, Box BM, Feleki V, Beaton JR. Bouts of exercise and food intake in the rat. $\mathcal{F}$ Appl Physiol 1966; 21: 118-22.

48 Ahrens RA, Bishop CL, Berdanier CD. Effect of age and dietary carbohydrate source on the responses of rats to forced exercise. I Nutr 1972; 102: 241-7.

49 Hill AB. A short textbook of medical statistics. London: Hodder and Stoughton, 1977.

50 Wood PD, Haskell WL. Interrelation of physical activity and nutrition on lipid metabolism. In: White PE, Mondeika T, eds. Diet and exercise: synergism in health maintenance. Chicago: American Medical Association, 1982: 39-47.

51 Weltman A, Matter S, Stamford BA. Caloric restriction and/or mild exercise: effects on serum lipids and body composition. Am 7 Clin Nutr 1980; 33: 1002-9.

52 Isaksson B. Nutrition in industrialised countries. Nutrition (London) 1973; 27: 307-11.

53 Mertz W. Mineral elements: new perspectives. 7 Am Diet Assoc 1980; 77: 258-63.

54 WHO Expert Committee. Prevention of coronary heart disease: WHO Tech Rep Ser 1982: 678.

55 Royal College of Physicians. Obesity. $\mathcal{R} R$ Coll Physicians Lond 1983; 17: 3-58. 